\title{
THE PRODUCT DEVELOPER IN THE CENTRE OF PRODUCT DEVELOPMENT: A SYSTEMATIC LITERATURE REVIEW ON DESCRIBING FACTORS
}

\author{
Albers, Albert; Heimicke, Jonas; Spadinger, Markus; Degner, Nadine; Duehr, Katharina \\ Karlsruhe Institute of Technology (KIT), IPEK - Institute for Product Engineering
}

\begin{abstract}
In the uncertain process of product development, the developer is decisively responsible for product success. He operates in a complex environment that directly influences his synthesis and analysis activities. The context of the socio-technical system of product development has already been extensively researched and defined by a large number of factors. However, the developer is described as part of the context and not as the centre, which means that many of these factors have no interaction with the developer. For the design of methods and tools that support the developer in his activities in the development process, a summarizing understanding of the influences on and by the developer is necessary. In order to create a unified understanding of the developer at the centre of product development, a Systematic Literature Review was conducted. In this article, the procedure and findings are presented. The aim was to identify factors from the literature that significantly influence the interaction of the developer in his environment. As a result, these were documented in a model, which represents the basis for further, human-centred research in the context of product development.
\end{abstract}

Keywords: Design engineering, Human behaviour in design, Design process, ASD - Agile Systems Design, Socio-technical system

\section{Contact:}

Albers, Albert

Karlsruhe Institute of Technology (KIT)

IPEK Institute of Product Engineering

Germany

albert.albers@kit.edu

Cite this article: Albers, A., Heimicke, J., Spadinger, M., Degner, N., Duehr, K. (2019) 'The Product Developer in the Centre of Product Development: A Systematic Literature Review on Describing Factors', in Proceedings of the 22nd International Conference on Engineering Design (ICED19), Delft, The Netherlands, 5-8 August 2019. DOI:10.1017/ dsi.2019.190 


\section{INTRODUCTION}

The product development process has always been characterized by uncertainties that can have a negative impact on costs, performance and project workflows (Thomke and Reinertsen, 1998). Nontransparent and latent customer requirements, great competitive pressure and a high dynamic characterize the context of product development (Schmidt et al., 2017). For product developers this means that they have to handle a multitude of factors with different influences and effects on the product development context (Gericke et al., 2013) in order to manage the continuous interplay between synthesis and analysis activities (Ruckpaul et al., 2014) in the product development process by making the right decisions (Snowden and Boone, 2007). To support product development teams in achieving different results, there is a variety of design methods (Bavendiek et al., 2018).

Since the product developer is significantly responsible for the later product design through his synthesis and analysis activities, there is a multitude of literature that discusses the role of the developer, for example in process design, product design or function implementation (see Systematic Literature Review of McCoy et al. (2009)). This leads to a direct relation between development mission and objectives, development context, development methods and the developer itself on the quality of development results (Sundström and Zika-Viktorsson, 2009). Since in this causal chain the product developer - the human being - is at the centre (Hales and Gooch, 2004) and is decisively responsible for product success through his work, methods and processes must be able to be adapted and scaled to his needs in order to support him in the best possible way (Albers and Lohmeyer, 2012). However, in view of the large number of opposing factors influencing the developer, this poses a major challenge. Previous contributions describe the context by influence factors whereas the respective effects on or by the developer is not described leading in the fact that the cause effect relationship based on the influence factors is described insufficiently. When cause-and-effect relationships between the factors are understood, methods can be developed specifically to reinforce or mitigate certain effects. For this reason, this article conducts an extensive literature search with regard to various influencing factors that directly affect or are influenced by the developer. Based on this, the understanding of the developer in the centre of product development shall be sharpened in order to support the future development process and method development with a condensate from the literature.

\section{STATE OF THE ART}

\subsection{Problem solving processes}

According to Dörner (1979), a problem generally consists of three components: an unwanted initial state (ACTUAL), which is to be transformed into a desired final state (TARGET), which can also be unknown or vague. A barrier prevents the transformation from the ACTUAL to the TARGET state. According to Dörner (1979), specific circumstances are transformed into a new state by means of specific operators during the problem-solving process. The attributes of problems mentioned by Dörner (2000) - lack of transparency, complexity, dynamics and lack of knowledge - were supplemented by the interconnectedness of variables, the intrinsic dynamics, the irreversibility of decisions, the flood of (partly also useless) information and finally by the side effects of decisions by Wild and Möller (2015). In the context of product development, requirements for engineering problems can also be described as networked, interdependent or even contradictory (Glock, 1998). According to Dörner (1979), a problem is highly networked when variables or attributes cannot be viewed in isolation due to strong dependencies. In addition, Pahl and Beitz (2013) state that engineering problems are accompanied by complexity and uncertainty.

The number of problem-solving methods used in research and practice is large (Albers et al., 2016). The general solving process by Pahl and Beitz consists of a basic scheme with individual steps of operations that are executed sequentially and can possibly be repeated (Pahl and Beitz, 2013). Another method is the procedure cycle by Ehrlenspiel that is divided into three operations consisting of task clarification, searching for solutions and selecting solutions (Ehrlenspiel and Meerkamm, 2013). The SPALTEN method by Albers is a universal approach for all kinds of problems. SPALTEN therefore consists of seven steps leading into a breathing process by steadily generating and condensing information (Albers et al., 2016). With the help of the SPALTEN process, large problems can be 
divided into smaller problems that are easier to manage. Due to the universal applicability in the most different levels of abstraction, it is possible to abstract the entire product development process by means of SPALTEN and also to apply it during the different activities in the individual phases. This enables the fractal structure of SPALTEN, in which each individual SPALTEN step can be modelled by another SPALTEN process (Albers and Braun, 2011).

\subsection{The human being as problem solver in product development}

Every product development process can be modelled as a problem-solving process (Albers and Braun 2011). Ferdinand Redtenbacher - the founder of scientific mechanical engineering - stated in early 1858 that the engineer not only assumed the task of combining science and craftsmanship, but also the task of a creative artist (Redtenbacher 1852). This statement shaped the way of thinking about the human as a central element in the product development process and thus as a problem solver (Redtenbacher and Krosigk 2007). According to Badke-Schaub and Frankenberger (2004), solving problems as a central activity in the product development process is primarily characterized by thinking. The human being with his cognitive abilities offers high potentials regarding abstraction, the ability to separate the important from the unimportant, to generate creative solutions and analogies as well as regarding the handling of preliminary information (Ehrlenspiel and Meerkamm 2013). In order to handle complexity and connectedness during the process, the problem solver switches between different levels of detail in the mental representation of the problem (Wynn et al. 2007).

Five general requirements for the cognitive processes in the problem solving process can be stated as follows: Reduction of information, modelling of the situation, prognosis of upcoming developments, collection and generation of information as well as evaluation of the objective (Greiff und Funke 2010). Costa and Sobek (2003) describe the process as the continuous generation of knowledge and identification of options for solution processes. The Acatech study from 2012 takes up these aspects and recommends reintroducing the concepts of system developer, whose focus is on synthesis, and validation engineer, whose focus is on analysis, according to the statement that an engineer as a problem solver must have both synthesis and analysis competencies (Albers et al. 2012).

\subsection{Model of product development as socio-technical system}

Product development can be understood as a socio-technical system, which models humans as the central system element (Albers and Lohmeyer, 2012; Buckl et al., 2014). This assumption is also taken into account when modelling development processes in different process models (Wynn and Clarkson, 2018). Using the understanding that product development is a socio-technical system, it can be modelled by the so-called System Triple of Product Development (see Figure 1.).

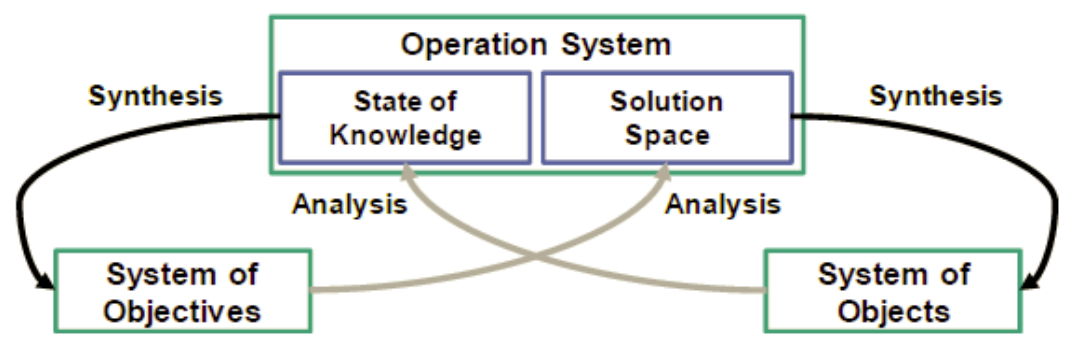

Figure 1. System Triple of Product Engineering, representation after (Albers et al., 2018)

The System Triple of Product Development describes the process of product development as continuous interaction of systems of objectives, systems of objects and operation systems (Ropohl, 1975). The system of objectives contains all product-specific objectives, their justification and interactions as well as the requirements and boundary conditions associated with them. The system of objects contains all results generated in the product development process (sketches, CAD models, prototypes, etc.) and finally the product itself. The maturity level of the system of objectives and the system of objects, which are connected exclusively via the operation system, is continuously increased in the course of a development project by the operation system through analysis and synthesis activities. The operation system contains developers who jointly derive product-specific objectives in a development project based on their knowledge base and further information which they generate from relevant objects. At the beginning of a project, the initial system of objectives is built up, which in turn spans an initially vague solution space which represents a developers' mental model. On this 
basis, the developers generate solutions (objects) that are consistent with the solution space. The generated objects are validated with regard to their target fulfilment and lead to an expansion of the knowledge base from which the system of objectives is in turn concretized. Accordingly, product development is a highly iterative process, since this cycle is continuously run through. (Albers et al., 2011)

This model makes it clear that any analysis and synthesis activities that are necessary for the continuous development of the product are carried out by developers. These activities are subject to various influences, which will be analyzed in more detail in this article.

\subsection{Context of product engineering}

Processes, methods and tools as well as the procedures of developers in different development projects must always be adapted to the respective development context in order to ensure sufficient acceptance of the development team for the methods on the one hand and to be practical with regard to the achievement of the respective development goal (Bucher and Dinter, 2012; Albers et al., 2014) on the other hand. It is obvious that the context must be understood in order to adapt methods in a suitable form (Gericke et al., 2013). The context describes connected conditions in which a particular object appears, exists or interacts. It is also dependent on the company's own attributes (Maffin et al., 1997). It is based on a multitude of factors, which in turn can have different influences, interactions and states depending on their characteristics. According to Gericke et al., (2013), the factors can be categorised into the clusters Macroeconomic, Microeconomic, Corporate, Project and Personnel. Their interactions determine the complexity of dealing with the effects caused by them (Gericke et al., 2013).

\section{RESEARCH DESIGN}

It is essential to understand the context as well as the developer and his interactions in the product development process in order to support development teams with regard to context- and projectdependent procedures and in the area of process and method research. The literature provides many approaches to build this understanding. As a result, the number and diversity of identified relevant influencing factors has continuously increased, which has led different schools to consider their own theories and different factors to be relevant. A model that was generated based on the understanding of the developer at the centre of product development and on the basis of relevant influencing factors that induce direct influence on the developer and factors that result from the actions of the developer is not known. In order to support future method development and process adaptation depending on influences resulting from dependencies of different factors with the product developer, this contribution aims to derive a comprehensive and factor-based understanding of the product developer at the centre of product development. In order to achieve this goal, the following research questions are answered in this paper:

1. Which factors from the literature describe the direct relation of the developer with his environment in the product development process?

2. What influence does this insight have on the understanding of the product developer at the centre of product development?

In order to answer the research questions, a Systematic Literature Review (Khan et al., 2003) is conducted with the aim of identifying literature that either understands the product developer as a central element in the system of product development, or describes factors that indicate a direct dependency between the developer and his environment. In order to further sharpen the understanding of the product developer at the centre of product development, further factors are determined by a free literature search. All factors were collected, clustered and classified as direct, indirect and directional in relation to the product developer. Based on the interpretation of the results, a model was derived that understands the product developer with regard to the factors at the centre of product development. The research work is based on type two of the Design Research Methodology (DRM) after Blessing and Chakrabati (2009, p. 18) according to which the Research Clarification and Descriptive Study 1 (in this case review-based) are comprehensive and conclude with an initial prescriptive study, the model development. 


\section{RESULTS}

\subsection{Systematic Literature Review}

The aim of the Systematic Literature Review was to examine the state of the literature regarding the understanding of the product developer at the centre of product development with regard to descriptive factors. In order to make it as comprehensive and at the same time thematically limited as possible, the search field was divided into three categories relevant to the research objective: developer, environment and product development. Within each of the three categories, term alternatives were formed. From these, various strings were derived, checked and compared by a combination and finally the string developer AND (environment OR context) AND ("product development" OR "product design") was selected for the Systematic Literature Review.

In order to eliminate studies and publications that were not relevant for the present research objective, various inclusion criteria were defined. The first and most important criterion was, that the literature deals with influences on the product developer and does not understand the customer or user as the focus of the development. In addition, at least one term alternative from each of the three categories had to appear in titles, abstracts or keywords. Furthermore, contributions without access (e.g. if the document was not deposited) were excluded. Another criterion was the language in which the article was written. Only literature written in German or English was examined. In addition, only peer reviewed literature was used.

The systematic literature review was conducted using the search engines Scopus and Google Scholar. The selection is based on the fact that these search engines search a large number of important databases such as Science Direct, IEEE, Design Society, Springer and ACM. Since Scopus and Google Scholar offer different search options, the search term was adapted to the options.

\begin{tabular}{|c|c|}
\hline $\begin{array}{c}\text { Google Scholar } \\
\text { (Springer, Science Direct, Design Society, ...) } \\
\text { 35 Paper }\end{array}$ & $\begin{array}{c}\text { Scopus } \\
\text { (Springer, Science Direct, Design Society, ...) } \\
\text { 418 Paper }\end{array}$ \\
\hline Exclude Duplicates \\
\hline 446 Paper \\
\hline Filter by Abstract \\
\hline 18 Paper \\
\hline Filter by Content \\
8 Paper \\
\hline
\end{tabular}

Figure 2. Search process and filtering steps

Figure 2. shows an overview of the search process as well as the number of contributions according to the individual filter steps. The first step of the research resulted in a total of 453 hits. Google Scholar delivered 35 and Scopus 418 contributions. In the following step, seven duplicates were identified from the 453 papers and eliminated. This resulted in a number of 446 papers, which were filtered again in the next step by analyzing the abstract and using the previously defined criteria. After this step 18 contributions remained, which were checked for usefulness by analysis of the full text and finally 8 papers were identified, which deal with the influences of and on the developer.

\subsection{Influencing factors on and by the product developer}

From the remaining eight contributions to the systematic literature search, 16 factors were identified that describe the interaction of the developer in the context of product development. These can be divided into two categories: Factors that affect the developer and factors that are determined by the developer's actions. In contrast to the influencing factors described in the current state of research, this contribution focuses not only in the factors themselves, but rather in the respective influence the different factors cause. 
Factors influencing the developer are: social support by executives (Todt et al. 2018), conflicts of objectives between developers and management (Terho et al. 2016), passing on customer feedback and new product ideas by dealers (Restuccia et al. 2016), environmental turbulence (Dayan and Di Benedetto 2011) and the combination of time pressure, management support and high project experience (ZikaViktorsson and Ingelgård 2006). The factors influenced by the developer include the size of the team, the duration of the team's existence, the strength of the relationships within the team, the degree of clustering within the team (Datta 2018), the team experience combined with intuitive cognitive decision making (Dayan and Di Benedetto 2011), the amount of reflective activities (Zika-Viktorsson and Ingelgård 2006), the personal integrity of the developer (Morton et al. 2006) and the team climate in combination with financial resource bottlenecks (Weiss, M. Hoegl, M. and Gibbert 2011). An overview of these factors and their impact is presented in Table 1. The factors from the free search are also stated in the table below:

Table 1. Factors affecting the developer

\begin{tabular}{|c|c|c|c|}
\hline Factor & Cluster & Effect & Source \\
\hline emotional leader's support & Personnel & higher project commitment & $\begin{array}{l}\text { (Todt et al. } \\
\text { 2018) }\end{array}$ \\
\hline $\begin{array}{l}\text { conflict between business-driven } \\
\text { and technical driven goals }\end{array}$ & Project & frustration for the developer & $\begin{array}{l}\text { (Terho et al. } \\
\text { 2016) }\end{array}$ \\
\hline $\begin{array}{l}\text { submission of customer } \\
\text { wishes/problems by dealers }\end{array}$ & $\begin{array}{l}\text { Micro- } \\
\text { economic }\end{array}$ & \multirow[t]{2}{*}{ quality and functional improvement } & \multirow[t]{3}{*}{$\begin{array}{l}\text { (Restuccia et } \\
\text { al. 2016) }\end{array}$} \\
\hline $\begin{array}{l}\text { submission of proposals for } \\
\text { solutions to costumer problems and } \\
\text { ideas for new functions }\end{array}$ & Project & & \\
\hline customer feedback & $\begin{array}{l}\text { Micro- } \\
\text { economic }\end{array}$ & new product ideas & \\
\hline larger teams & Project & \multirow[t]{2}{*}{ higher error rate } & \multirow[t]{4}{*}{ (Datta 2018) } \\
\hline $\begin{array}{l}\text { higher level of connection between } \\
\text { team members }\end{array}$ & Project & & \\
\hline longer existing teams & Project & \multirow[t]{2}{*}{ lower error rate } & \\
\hline higher solidarity within the team & Personnel & & \\
\hline $\begin{array}{l}\text { combination of moderate time } \\
\text { pressure, management support and } \\
\text { high project experience }\end{array}$ & $\begin{array}{l}\text { Project/Corpor } \\
\text { ate }\end{array}$ & more reflective activities & \multirow{2}{*}{$\begin{array}{l}\text { (Zika- } \\
\text { Viktorsson } \\
\text { and } \\
\text { Ingelgård } \\
\text { 2006) }\end{array}$} \\
\hline reflective activities & Project & $\begin{array}{l}\text { improvement of all project } \\
\text { management processes }\end{array}$ & \\
\hline $\begin{array}{l}\text { high team climate for innovation }+ \\
\text { financial resource constraints }\end{array}$ & Project & higher product quality & \multirow{2}{*}{$\begin{array}{l}\text { (Weiss, M. } \\
\text { Hoegl, M. } \\
\text { and Gibbert } \\
\text { 2011) }\end{array}$} \\
\hline $\begin{array}{l}\text { low team climate for innovation }+ \\
\text { financial resource constraints }\end{array}$ & Project & low project efficiency & \\
\hline environmental turbulences & Corporate & $\begin{array}{l}\text { positive influence on intuitive } \\
\text { decisions }\end{array}$ & \multirow{2}{*}{$\begin{array}{l}\text { (Dayan and } \\
\text { Di Benedetto } \\
\text { 2011) }\end{array}$} \\
\hline $\begin{array}{l}\text { team experience and intuitive- } \\
\text { cognitive decision making }\end{array}$ & Personnel & higher product creativity & \\
\hline $\begin{array}{l}\text { improving the personal integrity of } \\
\text { product developers }\end{array}$ & Personnel & improved decision-making & $\begin{array}{l}\text { (Morton et } \\
\text { al. 2006) }\end{array}$ \\
\hline \multicolumn{4}{|l|}{ Factors from free search } \\
\hline involvement of the user & Project & $\begin{array}{l}\text { reduced development time }+ \text { costs, } \\
\text { increased product quality }+ \text { success }\end{array}$ & $\begin{array}{l}\text { (Lettl 2007), } \\
\text { (Ismail 2005) }\end{array}$ \\
\hline $\begin{array}{l}\text { reward and recognition for the } \\
\text { developer's performance }\end{array}$ & Corporate & increase of innovation quality & (Koc 2007) \\
\hline positive discussion culture & Project & positive effect on team learning & (Ismail 2005) \\
\hline $\begin{array}{l}\text { competence, team spirit and } \\
\text { autonomy }\end{array}$ & Corporate & \multirow[t]{2}{*}{ increased motivation } & \multirow[t]{3}{*}{$\begin{array}{l}\text { (Noll et al. } \\
\text { 2017) }\end{array}$} \\
\hline intellectual challenge & Project & & \\
\hline high motivation & Project & $\begin{array}{l}\text { higher number of innovation, } \\
\text { success rate + product quality }\end{array}$ & \\
\hline
\end{tabular}




\begin{tabular}{|c|c|c|c|}
\hline quality of working environment & Corporate & \multirow[t]{4}{*}{ increased motivation } & \multirow{4}{*}{$\begin{array}{l}\text { (Verner et al. } \\
\text { 2014) }\end{array}$} \\
\hline communication quality & Project & & \\
\hline $\begin{array}{l}\text { project experience }+ \text { positive } \\
\text { associations }\end{array}$ & Project & & \\
\hline positive group climate & Project & & \\
\hline agile development & Project & higher degree of autonomy & $\begin{array}{l}\text { (Noll et al. } \\
\text { 2017) }\end{array}$ \\
\hline high problem pressure & Project & increased innovation activities & (Lettl 2007) \\
\hline cross-functional teams & Project & $\begin{array}{l}\text { increased understanding pf goals+ } \\
\text { ability to innovate }\end{array}$ & \multirow[t]{8}{*}{ (Koc 2007) } \\
\hline decentralized decisions processes & Project & increased innovation capacity & \\
\hline participation in scientific activities & Corporate & increased learning climate & \\
\hline positive learning climate & Corporate & $\begin{array}{l}\text { new ideas, increased creativity, gain } \\
\text { of new knowledge }\end{array}$ & \\
\hline disharmony & Project & $\begin{array}{l}\text { increased likelihood of } \\
\text { development failures }\end{array}$ & \\
\hline reduction of functional barriers & Corporate & accelerated problem solving & \\
\hline participation in training & Corporate & increased speed of innovation & \\
\hline high number of academics & Corporate & $\begin{array}{l}\text { higher number of product } \\
\text { innovations }\end{array}$ & \\
\hline
\end{tabular}

To identify, which areas of the product development context are covered, the factors have been assigned to the five different clusters introduced by Gericke et al., (2013) to get in inside if important areas are missing and if further investigations are necessary (see Table 1). It can be seen that the clusters of Corporate and Project are covered amply whereas the other clusters Macroeconomics, Microeconomics and Personnel are covered unsatisfactory.

\subsection{The product developer at the centre of product development}

The factors identified in the literature were related to the direction of their effect (on or by the developer) and to the question of whether they directly or indirectly influence the developer. These findings were modelled by describing the developer as the centre of product development (see Figure 3.).

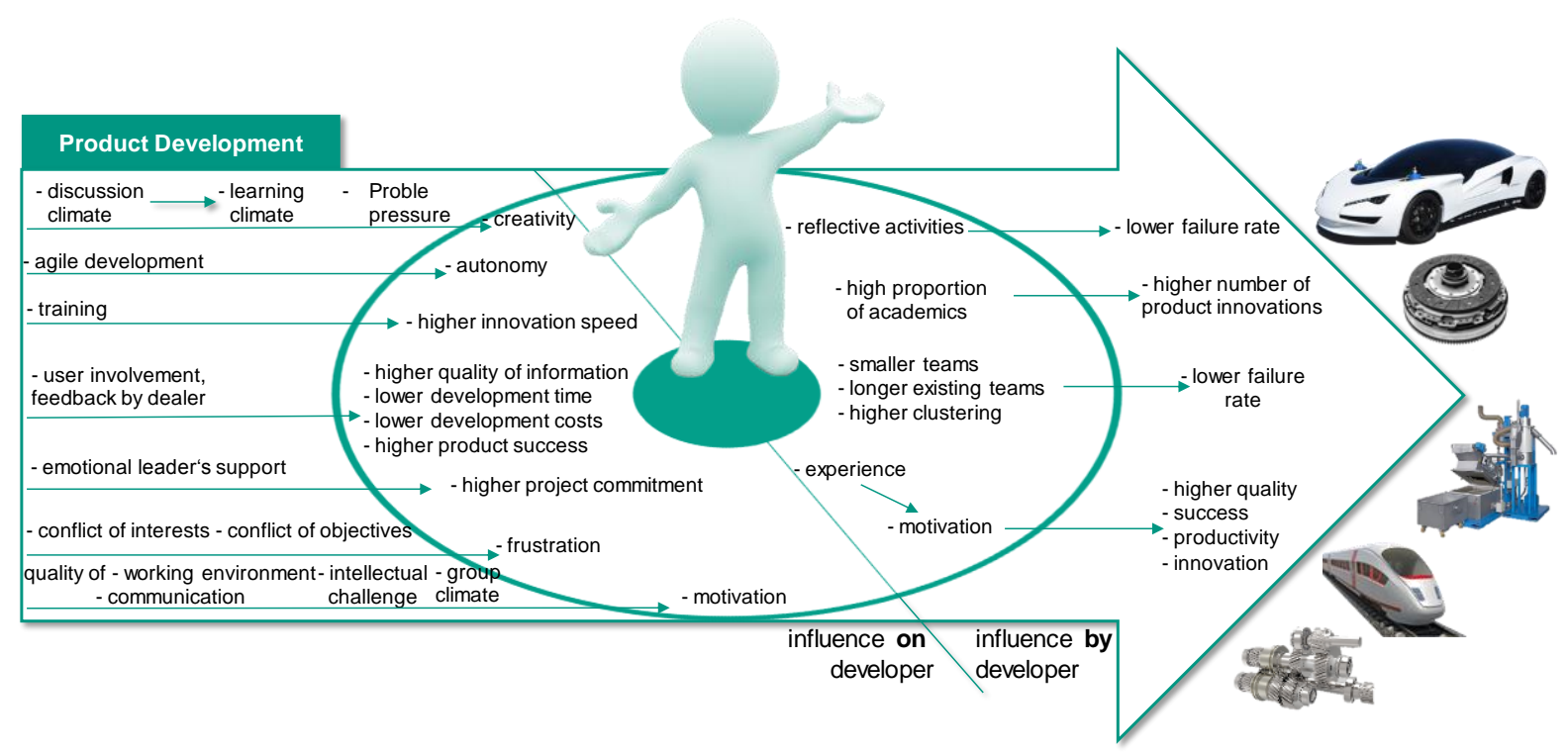

Figure 3. Developer in the Centre of Product Development

The product quality depends directly on the quality of the analysis and synthesis activities carried out by the developer. This in turn is influenced by the factor constellation shown in Figure 3. Accordingly, the discussion climate, learning climate and problem pressure, for example, directly influence the creativity of the developer, which in turn influences the number and quality of the solution alternatives generated by the developer in the process. On the side of the factors influenced by the developer, for example, it was derived from the literature that an academic background of the developer has a 
positive influence on the number of product innovations. Taking into account the System Triple of Product Development presented in Section 2.3, it is derived that the developer as part of the operation system is the centre of product development through the quality of his synthesis and analysis activities, which are influenced directly or indirectly by various factors and influence other factors directly or indirectly, and is thus directly responsible for product quality. This in turn affects the success of the company.

\section{CONCLUSION}

The Systematic Literature Review carried out in this research showed, that many scientific contributions model the entire context of product development using various factors, however, they did not model the cause-effect relationships in which the developer is involved. In addition, many scientific contributions focus on the customer or the user and his influence as well as his role in the product development process. With the aim of understanding the significance of the product developer at the centre of product development, a search string was formulated and applied to various scientific databases. The number of relevant literature that identified factors describing the interaction of the developer with his environment was good to handle. These, in turn, could be distinguished in terms of their direction of interaction of the developer (effect on the developer and effect by the developer) and their directness (direct or indirect interaction of the developer). Thus, the environment that affects the developer and the effects resulting from the developer's actions could be described by a selection of factors. The identified factor constellation interacts directly with the developer in performing his synthesis and analysis activities, which in turn directly influence the quality of the product. This contribution has sharpened the overall understanding of the product developer as the centre of product development. The understanding of the cause-effect relationships in which the developer is involved in the process can be used to describe the mechanisms of development methods in detail. Furthermore, in the context of agile processes (Albers et al. 2019), for example, principles of product development can be operationalized with regard to the stimulation or minimization of factor effects.

The cause-effect relationships can be used in future research work to be consulted in method development or to better adapt the development context to the requirements of the developer. In addition, the understanding created in this contribution can be used to continuously focus research on the product developer when researching current topics such as the design of agile approaches or method development for distributed collaborating development teams, thus avoiding the creation of inappropriate methods and approaches that fail to meet the needs of the developer.

However, it should be added to the presented results, that the factors in the identified model do not claim to be complete. In addition, the quality of the findings is directly dependent on the quality of the search string. This means that immediate research can pursue the goal of extending the completeness of the model.

\section{REFERENCES}

Albers, A. and Braun, A. (2011), “A generalised framework to compass and to support complex product engineering processes", International Journal of Product Development, Vol. 15 No. 1/3, pp. 6-25, https://doi.org/10.1504/IJPD.2011.043659.

Albers, A., Denkena, B., Matthiesen, S., Dengler, B., Hoppen, P., Marxen, L. et al. (2012): Faszination Konstruktion - Berufsbild und Tätigkeitsfeld im Wandel. In: Acatech Studie, ISBN 978-3-642-31930-3.

Albers, A., Heimicke, J., Walter, B., Basedow, G.N., Reiß, N., Heitger, N., Ott, S. and Bursac, N. (2018), "Product Profiles. Modelling customer benefits as a foundation to bring inventions to innovations", Procedia CIRP, Vol. 70 No. 1, pp. 253-258, https://dx.doi.org/10.1016/j.procir.2018.02.044.

Albers, A., Heimicke, J., Spadinger, M., Reiss, N., Breitschuh, J., Richter, T., Bursac, N. and Marthaler, F. (2019), "Eine Systematik zur situationsadäquaten Mechatroniksystementwicklung durch ASD - Agile Systems Design”, in KIT Scientific Working Papers, Vol. 113, KIT, Karlsruhe. https://dx.doi.org/10.5445/IR/1000091847.

Albers, A. and Lohmeyer, Q. (2012), “ADVANCED SYSTEMS ENGINEERING - TOWARDS A MODELBASED AND HUMAN-CENTERED METHODOLOGY”, in Horváth, I. (Ed.), Tools and methods of competitive engineering: Proceedings of the Ninth International Symposium on Tools and Methods of Competitive Engineering, TMCE 2012, Delft, pp. 407-416.

Albers, A., Lomeyer, Q. and Ebel, B. (2011), DIMENSIONS OF OBJECTIVES IN INTERDISCIPLINARY PRODUCT DEVELOPMENT PROJECTS, INTERNATIONAL CONFERENCE ON ENGINEERING DESIGN, ICED11, Copenhagen, Denmark. 
Albers, A., Reiß, N., Bursac, N. and Breitschuh, J. (2016), “15 Years of SPALTEN Problem Solving Methodology in Product Development", in Boks, C. (Ed.), Proceedings of NordDesign 2016: August 1012, 2016, Trondheim, Norway, The Design Society, Bristol, United Kingdom, pp. 411-420.

Albers, A., Reiß, N., Bursac, N., Urbanec, J. and Lüdcke, R. (2014), "Situation-appropriate method selection in product development process - empirical study of method application", Proceedings of NordDesign 2014 Conference, pp. 550-559.

Badke-Schaub, P. and Frankenberger, E. (2004): Management Kritischer Situationen. Produktentwicklung erfolgreich gestalten. Springer (VDI-Buch), Berlin, Heidelberg. http://dx.doi.org/10.1007/978-3-64218702-5.

Bavendiek, A.-K., Huth, T., Inkermann, D., Paulsen, H., Vietor, T. and Kauffeld, S. (2018), "COLLABORATIVE DESIGN: LINKING METHODS, COMMUNICATION TOOLS AND COMPETENCIES TO PROCESSES”, in Proceedings of the DESIGN 2018 15th International Design Conference; The Design Society, Glasgow, UK, pp. 149-160, http://dx.doi.org/10.21278/idc.2018.0420.

Blessing, L.T.M. and Chakrabarti, A. (2009), DRM, a design research methodology, Springer, Dordrecht, London, http://dx.doi.org/10.1007/978-1-84882-587-1.

Bucher, T. and Dinter, B. (2012), "Situational Method Engineering to Support Process-Oriented Information Logistics", Journal of Database Management, Vol. 23 No. 1, pp. 31-48, http://dx.doi.org/10.4018/jdm.2012010102.

Buckl, S., Matthes, F. and Schweda, C.M. (2014), "Socio-technic Dependency and Rationale Models for the Enterprise Architecture Management Function”, in Bayro-Corrochano, E. and Hancock, E. (Eds.), Progress in Pattern Recognition, Image Analysis, Computer Vision, and Applications, Lecture Notes in Computer Science, Vol. 8827, Springer International Publishing, Cham, pp. 528-540, http://dx.doi.org/10.1007/978-3-642-22056-2_54.

Costa, R. and Sobek, D. K. (2003), Iteration in engineering design: inherent and unavoidable or product of choices made? In: ASME 2003 International design engineering technical conferences and Computers and information in engineering conference. American Society of Mechanical Engineers. https://doi.org/10.1115/DETC2003/DTM-48662

Datta, S. (2018), "How does developer interaction relate to software quality? an examination of product development data”, Empirical Software Engineering, Vol. 23 No. 3, pp. 1153-1187. https://doi.org/10.1007/s10664-017-9534-0

Dayan, M. and Di Benedetto, C. A. (2011), Team intuition as a continuum construct and new product creativity: The role of environmental turbulence, team experience, and stress. In: Research Policy Vol. 40 No. 2, S. pp. 276-286. https://doi.org/10.1016/j.respol.2010.10.002

Dörner, D. (1979), Problemlösen als Informationsverarbeitung, Kohlhammer-Standards Psychologie Studientext, Vol. 2. Aufl., Kohlhammer, Stuttgart.

Dörner, D. (2000), Die Logik des Mißlingens: Strategisches Denken in komplexen Situationen, Rororo RororoSachbuch Rororo science, Vol. 19314, No. 13. Aufl., Rowohlt, Reinbek bei Hamburg.

Ehrlenspiel, K. and Meerkamm, H. (2013), Integrierte Produktentwicklung: Denkabläufe, Methodeneinsatz, Zusammenarbeit, 5th ed., München: Carl Hanser Verlag, http://dx.doi.org/10.3139/9783446436275.

Gericke, K., Meißner, M. and Paetzold, K. (2013), "Understanding the context of product development", DS 753: Proceedings of the 19th International Conference on Engineering Design (ICED13) Design For Harmonies, Vol. 75 No. 3.

Glock, F. (1998), Konstruieren als sozialer Prozeß: Eine Untersuchung technischen Gestaltens, Deutscher Universitätsverlag, Wiesbaden. https://doi.org/10.1007/978-3-322-99953-5

Greiff, S. and Funke, J. (2010), "Systematische Erforschung komplexer Problemlösefähigkeit anhand minimal komplexer Systeme”. Projekt Dynamisches Problemlösen. In: Z. Für Pädagog No. 56, S. pp. 216-227.

Hales, C. and Gooch, S. (2004), Managing Engineering Design. 2nd ed. Springer-Verlag, London. https://doi.org/10.1007/978-0-85729-394-7

Ismail, M. (2005), "Creative climate and learning organization factors: their contribution towards innovation". In: Leadership \& Org Development J Vol. 26 No. 8, S. pp. 639-654. https://doi.org/10.1108/01437730510633719.

Khan, K.S., Kunz, R., Kleijnen, J. and Antes, G. (2003), "Five steps to conducting a systematic review", Journal of the Royal Society of Medicine, Vol. 96 No. 3, pp. 118-121. https://doi.org/10.1177/014107680309600304

Koc, T. (2007), "Organizational determinants of innovation capacity in software companies", Computers \& Industrial Engineering, Vol. 53 No. 3, pp. 373-385, https://doi.org/10.1016/j.cie.2007.05.003.

Lettl, C. (2007), "User involvement competence for radical innovation", Journal of Engineering and Technology Management, Vol. 24 No. 1-2, pp. 53-75, https://doi.org/10.1016/j.jengtecman.2007.01.004.

Maffin, D., Thwaites, A., Alderman, N., Braiden, P. and Hills, B. (1997), "Managing the product development process: combining best practice with company and project contexts", Technology Analysis \& Strategic Management, Vol. 9 No. 1, pp. 53-76. https://doi.org/10.1080/09537329708524269 
McCoy, A.P., Thabet, W. and Badinelli, R. (2009), "Understanding the role of developer/builders in the concurrent commercialization of product innovation", European Journal of Innovation Management, Vol. 12 No. 1, pp. 102-128. https://doi.org/10.1108/14601060910928193

Morton, S.C., Brookes, N.J., Dainty, A.R.J., Backhouse, C.J. and Burns, N.D. (2006), "The Role of Social Relationships in Improving Product Development Decision Making”, Proceedings of the Institution of Mechanical Engineers, Part B: Journal of Engineering Manufacture, Vol. 220 No. 6, pp. 1017-1024, https://doi.org/10.1243/09544054JEM451SC.

Noll, J., Razzak, M.A. and Beecham, S. (2017), "Motivation and Autonomy in Global Software Development", in Mendes, E., Counsell, S. and Petersen, K. (Eds.), Proceedings of the 21st International Conference on Evaluation and Assessment in Software Engineering - EASE'17, Karlskrona, Sweden, ACM Press, New York, USA, pp. 394-399. https://doi.org/10.1145/3084226.3084277

Pahl, G. and Beitz, W. (2013), Konstruktionslehre: Methoden und Anwendung erfolgreicher Produktentwicklung.

Redtenbacher, F. (1852), Prinzipien der Mechanik und des Maschinenbaues. Bassermann Verlag, Mannheim.

Redtenbacher, F. J., Krosigk, E. von (2007), Prinzipien der Mechanik und des Maschinenbaus. Vol. 1. VDM, Müller, Aufl. Saarbrücken, (Edition classic).

Restuccia, M., Brentani, U., Legoux, R. and Ouellet, J.-F. (2016), "Product Life-Cycle Management and Distributor Contribution to New Product Development", Journal of Product Innovation Management, Vol. 33 No. 1, pp. 69-89, https://doi.org/10.1111/jpim.12261.

Ropohl, G. (1975), Einführung in die Systemtechnik.: Systemtechnik-Grundlagen und Anwendungen, Carl Hanser Verlag, München.

Ruckpaul, A., Kriltz, A. and Matthiesen, S. (2014), "Using eye tracking to understand the engineering designers' behavior in synthesis-driven analyzing processes: experiences in study design", International conference on human behavior in design HBiD.

Schmidt, T.S., Weiss, S. and Paetzold, K. (2017), “Agile Development of Physical Products. An Empirical Study about Motivations, Potentials and Applicability", University of the German Federal Armed Forces.

Snowden, D.J. and Boone, M.E. (2007), “A Leader's Framework for Decision Making”, Harvard business review, Vol. 85 No. 11, pp. 68-77.

Sundström, P. and Zika-Viktorsson, A. (2009), "Organizing for innovation in a product development project", International Journal of Project Management, Vol. 27 No. 8, pp. 745-753. https://doi.org/10.1016/j.ijproman.2009.02.007

Terho, H., Suonsyrjä, S. and Systä, K. (2016), “The Developers Dilemma: Perfect Product Development or Fast Business Validation?” in Abrahamsson, P., Jedlitschka, A., Nguyen Duc, A., Felderer, M., Amasaki, S. and Mikkonen, T. (Eds.), Product-Focused Software Process Improvement, Lecture Notes in Computer Science, Vol. 10027, Springer International Publishing, Cham, pp. 571-579. https://doi.org/10.1007/978-3319-49094-6_42

Thomke, S. and Reinertsen, D. (1998), “Agile Product Development: Managing Development Flexibility in Uncertain Environments”, California Management Review, Vol. 41 No. 1, pp. 8-30. https://doi.org/10.2307/41165973

Todt, G., Weiss, M. and Hoegl, M. (2018), "Mitigating Negative Side Effects of Innovation Project Terminations: The Role of Resilience and Social Support", Journal of Product Innovation Management, Vol. 35 No. 4, pp. 518-542, https://doi.org/10.1111/jpim.12426.

Verner, J.M., Babar, M.A., Cerpa, N., Hall, T. and Beecham, S. (2014), "Factors that motivate software engineering teams: A four country empirical study", Journal of Systems and Software, Vol. 92, pp. 115127, https://doi.org/10.1016/j.jss.2014.01.008.

Weiss, M., Hoegl, M., and Gibbert, M. (2011), "Making Virtue of Necessity: The Role of Team Climate for Innovation in Resource-Constrained Innovation Projects", Journal of Product Innovation Management, Vol. 28 No.s1, pp. 196-207, https://doi.org/10.1111/j.1540-5885.2011.00870.x.

Wild, E. and Möller, J. (2015), Pädagogische Psychologie, Springer Berlin Heidelberg, Berlin, Heidelberg. Wynn, D.C. and Clarkson, P.J. (2018), "Process models in design and development", Research in Engineering Design, Vol. 29 No. 2, pp. 161-202. https://doi.org/10.1007/s00163-017-0262-7

Wynn, D. C.; Eckert, C. M.; Clarkson, P. J. (2007): Modelling Iteration in Engineering Design. In: 16th International Conference on Engineering Design ICED'07.

Zika-Viktorsson, A. and Ingelgård, A. (2006), "Reflecting activities in product developing teams: conditions for improved project management processes", Research in Engineering Design, Vol. 17 No. 2, pp. 103-111. https://doi.org/10.1007/s00163-006-0019-1 